OPEN DEMOCRACY 



\section{Open Democracy}

Reinventing

\section{Popular Rule for}

the Twenty-First

Century

Hélène Landemore 
Copyright ( 2020 by Princeton University Press

Requests for permission to reproduce material from this work should be sent to permissions@press.princeton.edu

Published by Princeton University Press

41 William Street, Princeton, New Jersey 08540

6 Oxford Street, Woodstock, Oxfordshire OX20 ITR

press.princeton.edu

All Rights Reserved

Library of Congress Cataloging-in-Publication Data

Names: Landemore, Hélène, 1976- author.

Title: Open democracy : reinventing popular rule for the twenty-first century / Hélène Landemore.

Description: Princeton : Princeton University Press, [2020] | Includes bibliographical references and index.

Identifiers: LCCN 2020022229 (print) | LCCN 2020022230 (ebook) | ISBN 9780691181998 (hardcover) | ISBN 9780691212395 (paperback) | ISBN 9780691208725 (ebook)

Subjects: LCSH: Deliberative democracy. | Representative government and representation. | Political participation. | Deliberative democracy-Iceland-Case studies.

Classification: LCC JC423 .L3356 2020 (print) | LCC JC423 (ebook) | DDC 321.8-dc23

LC record available at https://lccn.loc.gov/2020022229

LC ebook record available at https://lccn.loc.gov/2020022230

British Library Cataloging-in-Publication Data is available

Editorial: Matt Rohal

Production Editorial: Kathleen Cioffi

Jacket Design: Layla Mac Rory

Production: Erin Suydam

Publicity: Kate Hensley and Kate Farquhar-Thomson

Copyeditor: Karen Verde

This book has been composed in Adobe Text and Gotham

Printed on acid-free paper. $\infty$

Printed in the United States of America

$109987 \begin{array}{llllll}10 & 5 & 4 & 3 & 2 & 1\end{array}$ 
To Sophie and Émilie 
